\title{
$19: 56946962-56940839$
}

National Cancer Institute

\section{Source}

National Cancer Institute. 19: 56946962-56940839. NCI Thesaurus. Code C42334.

Physical location of FPR1_Gene 